УДК 343.1

DOI https://doi.org/10.32844/2618-1258.2019.6.53

БОЖИк В.I.

\title{
СТАНДАРТИ ДОКАЗУВАННЯ У ПРОВАДЖЕННІ ПРО КРИМІНАЛЬНІ ПРОСТУПКИ
}

\begin{abstract}
У статті розкрито поняття доказування, його суть та значення у кримінальному провадженні. Проаналізовано визначення предмету та обсягу доказування у кримінальному процесі. Розглянуто питання доказів у провадженні щодо кримінальних проступків та їх процесуальних джерел. Наголошено, що дослідження інституту доказування саме на стадії дізнання має важливе значення з огляду на встановлену у законодавстві можливість спрощеного провадження щодо кримінальних проступків, яке передбачає можливість ухвалення судом вироку без дослідження доказів у судовому засіданні або на основі їх часткового дослідження. 3'ясовано, що в теорії кримінального процесу докази розуміють як органічну єдність фактичних даних, отриманих і закріплених у відповідній процесуальній формі, а також їх процесуальних джерел, на підставі якої сторони кримінального провадження слідчий суддя і суд встановлюють наявність чи відсутність фактів та обставин, що мають значення для кримінального провадження і підлягають доказуванню та яка визнана доказом уповноваженими суб'єктами доказування, слідчим суддею та судом. Окреслено, що до критеріїв допустимості доказів у науці кримінального процесу традиційно відносять: 1) належний суб'єкт, правомочний провадити процесуальні дії, спрямовані на формування доказів; 2) надійність фактичних даних, що складають зміст доказу; 3) дотримання вимог процесуальної форми під час формування відповідного виду доказів; 4) етичність тактичних прийомів, які використовуються для одержання доказів. Зроблено висновок, що результати медичного освідування та висновок спеціаліста, які надані до внесення відомостей до Єдиного реєстру досудового розслідування, можуть використовуватись в межах такого джерела доказів, як документи. Крім того, медичне освідування у кримінальному провадженні має здійснюватись в межах такої слідчої дії, як освідування особи, що передбачена ст. 241 КПК України. Вказане сприятиме забезпеченню прав осіб у провадженні щодо кримінальних проступків, адже саме додержання кримінальної процесуальної форми є запорукою ефективного виконання завдань кримінального провадження $з$ додержанням балансу інтересів держави і особи.
\end{abstract}

Ключові слова: кримінальне провадження, кримінальні проступки, доказування, предмет доказування.

The article reveals the concept of evidence, its essence and significance in criminal proceedings. The definition of the subject and scope of evidence in criminal proceedings is analyzed. The issue of evidence in criminal proceedings and their procedural sources is considered. It is emphasized that the study of the institution of evidence at the stage of inquiry is important given the possibility of simplified criminal proceedings, which provides for the possibility of a court verdict without examining the evidence in court or on the basis of their partial examination. It was found that in the

(C) БОЖИК В.І. - аспірант (Інститут права імені князя Володимира Великого Міжрегіональної академії управління персоналом) 
theory of criminal procedure evidence is understood as an organic unity of factual data obtained and fixed in the appropriate procedural form, as well as their procedural sources, on the basis of which the parties, criminal investigator and court establish the presence or absence of facts and circumstances relevant to the criminal proceedings and subject to proof, and which is recognized as evidence by the authorized subjects of proof, the investigating judge and the court. It is outlined that the criteria of admissibility of evidence in the science of criminal procedure traditionally include: 1) the appropriate subject, authorized to conduct procedural actions aimed at the formation of evidence; 2) the reliability of the factual data that make up the content of the evidence; 3 ) compliance with the requirements of the procedural form in the formation of the relevant type of evidence; 4) the ethics of tactics used to obtain evidence. It is concluded that the results of the medical examination and the conclusion of the specialist, which are provided before entering the information into the Unified Register of Pre-trial Investigation, can be used within such a source of evidence as documents. In addition, the medical examination in criminal proceedings must be carried out within the scope of such an investigative action as the examination of a person under Art. 241 of the Criminal Procedure Code of Ukraine. This will help ensure the rights of individuals in criminal proceedings, because compliance with the criminal procedural form is the key to effective implementation of the tasks of criminal proceedings with a balance of interests of the state and the individual.

Key words: criminal proceedings, criminal misdemeanors, evidence, subject of proof.

Вступ. Важливим складником будь-якого кримінального провадження $є$ доказування, яке здійснюється його учасниками з метою встановлення істини у справі. Доказування складає основний зміст діяльності більшості учасників кримінального провадження і має здійснюватись у межах кримінальної процесуальної форми. Оновлення доктрини кримінального процесу з прийняттям Кримінального процесуального кодексу України (далі КПК України) 2012 року визначило пріоритетним у процесі доказування забезпечення прав особи, внаслідок чого встановлені додаткові гарантії їх додержання. Забезпечення прав особи під час доказування у кримінальному провадженні вимагає чіткого закріплення процедури доказування у чинному законодавстві.

Досудове розслідування кримінальних проступків, яке здійснюється у формі дізнання, також нерозривно пов'язане з доказуванням, яке у вказаному провадженні має свої особливості, зумовлені його специфікою. Дослідження інституту доказування саме на стадії дізнання має важливе значення з огляду на встановлену у законодавстві можливість спрощеного провадження щодо кримінальних проступків, яке передбачає можливість ухвалення судом вироку без дослідження доказів у судовому засіданні або на основі їх часткового дослідження.

Стан дослідження. Дослідженню проблем доказування у кримінальному провадженні присвятили свої праці такі науковці, як С.А. Альперт, М.І. Бахін, О.В. Баулін, Т.В. Варфоломєєва, В.В. Гевко, В.Г. Гончаренко, Ю.М. Грошевий, В.С. Зеленецький, А.В. Іщенко, О.В. Капліна, Г.К. Кожевніков, В.О. Коновалова, В.С. Кузьмічов, В.Г. Лукашевич, Є.Д. Лук'янчиков, В.Т. Маляренко, О.Р. Михайленко, М.М. Михеєнко, В.Т. Нор, Г.М. Омельяненко, Д.П. Письменний, М.В. Салтевський, С.М. Стахівський, В.М. Тертишник та інші.

Постановка завдання. Разом з тим питання доказування у провадженні щодо кримінальних проступків не досліджено у вітчизняній кримінальній процесуальній науці належним чином, а тому є необхідність розкрити цей аспект.

Результати дослідження. У доктрині кримінального процесу є різні погляди на поняття доказування. М.С. Строгович вказує, що доказування полягає в установленні за допомогою доказів усіх фактів, обставин, які мають значення для вирішення кримінальної справи - вчинення чи невчинення злочину, винність (або невинність) тієї чи іншої особи в учиненні злочину та всіх інших обставин, що визначають відповідальність особи, яка вчинила злочин [1, с. 295]. М.М. Михеєнко вважає, що доказування - це діяльність суб'єктів кримінального процесу щодо збирання (формування), перевірки й оцінки доказів та їх процесуальних джерел, а також формулювання на цій підставі певних тез і наведення аргументів для їх обгрунтування [2, с. 120]. В.Т. Нор розглядає доказування як діяльність органів розслідування, прокурора і суду, а також інших учасників процесу, яка здійснюється у встановлених законом процесуальних формах і спрямована на збирання, закріплення, перевірку і оцінку фактичних даних (доказів), необхідних для встановлення істини у кримінальній справі [2, с. 75]. 
B.M. Тертишник визначає доказування як здійснювану в передбаченому законом порядку діяльність органів дізнання, слідчого, прокурора та суду за участі інших суб' єктів процесуальних правовідносин зі збирання, дослідження, перевірки й оцінки фактичних даних (доказів), використання їх у встановленні істини в справі, обгрунтуванні висновків і прийнятті рішень [3, с. 170]. C.M. Стахівський стверджує, що кримінально-процесуальне доказування - це передбачена законом діяльність суб'єктів кримінального процесу зі збирання (формування), перевірки й оцінки доказів та їх процесуальних джерел, прийняття на цій основі певних процесуальних рішень $\mathrm{i}$ наведення аргументів для їх обгрунтування (мотивації) [4, с. 21]. В той же час оцінка зібраних доказів не завжди тягне за собою припинення процесу доказування, а може призвести до необхідності збирання та перевірки нових доказів [5, с. 139].

Аналіз наведених визначень дозволяє стверджувати, що доказування у кримінальному провадженні - це передбачена кримінальним процесуальним законом діяльність суб'єктів кримінального провадження зі збирання, перевірки й оцінки доказів та їх процесуальних джерел, обгрунтування та прийняття процесуальних рішень.

Аналогічне положення міститься у ч. 2 ст. 91 КПК України, відповідно до якого доказування полягає у збиранні, перевірці та оцінці доказів з метою встановлення обставин, що мають значення для кримінального провадження [6]. Сукупність обставин, які підлягають доказуванню у кожному кримінальному провадженні, визначено у ч. 1 ст. 91 КПК України. Так, за загальним правилом у кримінальному провадженні підлягають доказуванню: 1) подія кримінального правопорушення (час, місце, спосіб та інші обставини вчинення кримінального правопорушення); 2) винуватість обвинуваченого у вчиненні кримінального правопорушення, форма вини, мотив і мета вчинення кримінального правопорушення; 3) вид і розмір шкоди, завданої кримінальним правопорушенням, а також розмір процесуальних витрат; 4) обставини, які впливають на ступінь тяжкості вчиненого кримінального правопорушення, характеризують особу обвинуваченого, обтяжують чи пом'якшують покарання, які виключають кримінальну відповідальність або є підставою для закриття кримінального провадження; 5) обставини, що $є$ підставою для звільнення від кримінальної відповідальності або покарання; 6) обставини, які підтверджують, що гроші, цінності та інше майно, які підлягають спеціальній конфіскації, одержані внаслідок вчинення кримінального правопорушення та/або $є$ доходами від такого майна, або призначалися (використовувалися) для схиляння особи до вчинення кримінального правопорушення, фінансування та/або матеріального забезпечення кримінального правопорушення чи винагороди за його вчинення, або є предметом кримінального правопорушення, у тому числі пов'язаного з їх незаконним обігом, або підшукані, виготовлені, пристосовані або використані як засоби чи знаряддя вчинення кримінального правопорушення; 7) обставини, що є підставою для застосування до юридичних осіб заходів кримінально-правового характеру [7].

Вказані обставини у сукупності є предметом доказування у кримінальному провадженні. В теорії кримінального процесу предмет доказування визначають як передбачену кримінальним процесуальним законом сукупність обставин, які підлягають обов'язковому встановленню у кожному кримінальному провадженні з метою ефективного виконання завдань кримінального провадження $[8$, c. $48 ; 9$, с. $44 ; 10$, с. 47$]$.

Обставини загального предмета доказування можуть конкретизуватися і доповнюватися у кримінальних провадженнях стосовно неповнолітніх (ст. 485 КПК України), про суспільно небезпечні діяння неосудних (ст. 505 КПК України), а також провадженнях, які здійснюються на підставі угод (ст. ст. 470-472, ч. 1 ст. 474 КПК України), стосовно окремої категорії осіб (ст. ст. 480-482 КПК України), за заявами приватного обвинувачення (ст.ст. 477, 478 КПК України) тощо.

Слід вказати, що у провадженні щодо кримінальних проступків предмет доказування $€$ загальним і не потребує уточнення в законі. В той же час не всі обставини, визначені ст. 91 КПК України, підлягають доказуванню у провадженні щодо кримінальних проступків. Це обставини, що є підставою для застосування до юридичних осіб заходів кримінально-правового характеру.

Окремо слід розглянути питання доказів у провадженні щодо кримінальних проступків та їх процесуальних джерел. Поняття доказів $є$ фундаментальною правовою категорією, без якої неможливе судочинство. Визначення в законодавстві системи доказів з урахуванням необхідності забезпечення прав особи, їх відповідне розуміння учасниками кримінального провадження сприяє ефективному виконанню завдань кримінального провадження.

У теорії кримінального процесу докази розуміють як органічну єдність фактичних даних, отриманих і закріплених у відповідній процесуальній формі, а також їх процесуальних джерел, на підставі якої сторони кримінального провадження, слідчий суддя і суд встановлюють наяв- 
ність чи відсутність фактів та обставин, що мають значення для кримінального провадження і підлягають доказуванню, та яка визнана доказом уповноваженими суб'єктами доказування, слідчим суддею та судом [11, с. 16$]$.

C.M. Стахівський вказує, що під доказами у кримінальному судочинстві слід розуміти будь-які відомості про факти, котрі одержані в установленому законом порядку та за допомогою яких орган розслідування, прокурор і суд встановлюють наявність чи відсутність суспільно-небезпечного діяння, винуватість або невинуватість особи, яка його вчинила, та решту обставин, що мають значення для встановлення істини і правильного вирішення справи. Ні слідчий, ні суд не можуть оперувати фактами, а лише знаннями (відомостями) про ці факти. I саме ці відомості про факти допомагають слідчому відновити модель події, яка мала місце в минулому. Не слід також об'єднувати в одне ціле зміст і форму доказів, тобто відомості про факти і їх процесуальне джерело. Звичайно, вони органічно пов'язані між собою, але не утворюють одного цілого [12, с. 146-147].

О.В. Баулін, досліджуючи поняття доказів у кримінальному процесі, зазначає, що процесуальні джерела доказів $\epsilon$ не що інше, як процесуальна форма існування і зберігання відомостей про факти як доказів у кримінальному процесі. Без втілення в цю процесуальну форму фактичні дані не мають значення доказу, а порушення процесуальної форми їх залучення до сфери кримінально-процесуального доказування призводить до визнання доказу недопустимим. Застосоване у цьому контексті поняття процесуальної форми акумулює в собі усі вимоги законодавчої регламентації порядку кримінального провадження, як загальні, так і спеціальні, у тому числі щодо правил, процедур, послідовності, строків проведення слідчих (розшукових) та інших процесуальних дій, що прямо або опосередковано пов'язані зі збиранням (формуванням), перевіркою та дослідженням доказів під час досудового розслідування і судового розгляду, їх закріпленням у процесуальних актах, а також порядок прийняття і оформлення рішень з окремих питань доказування і у кримінальному провадженні загалом [13, с. 76].

Відповідно до ч. 1 ст. 84 КПК України доказами в кримінальному провадженні $є$ фактичні дані, отримані у передбаченому цим Кодексом порядку, на підставі яких слідчий, прокурор, слідчий суддя і суд встановлюють наявність чи відсутність фактів та обставин, що мають значення для кримінального провадження та підлягають доказуванню.

В основу вказаного визначення законодавцем покладена інформаційна модель доказів, відповідно до якої докази - це єдність фактичних даних (даних про факти) та їх процесуальних джерел. Такий підхід до визначення поняття доказів грунтується на теорії відбиття, згідно з якою подія кримінального правопорушення для органів досудового провадження, прокурора, захисника та суду є минулою. Кримінальне правопорушення - це певна сукупність відповідних явищ, предметів, процесів, що відбуваються в оточуючому середовищі. Вступаючи в контакт з багатьма іншими явищами об'єктивної дійсності, воно залишає відбиття на матеріальних об'єктах у формі матеріальних слідів (станів предметів, динамічних і статичних процесів тощо), а також у формі ідеальних слідів - у свідомості людей. Це дає можливість відтворити «картину» вчиненого кримінального правопорушення діяння або встановити його відсутність [14, с. 247].

В той же час надане законодавцем визначення доказів не включає в доказування дізнавача. Крім того, у ст. 92 КПК України, у якій визначені суб'єкти доказування, дізнавач також не вказаний. Проте у ч. 1 ст. 93 КПК України зазначено, що збирання доказів здійснюється сторонами кримінального провадження, потерпілим, представником юридичної особи, щодо якої здійснюється провадження. Така ситуація в майбутньому може призвести до випадків визнання недопустимими доказів, отриманих дізнавачем у провадженні щодо кримінальних проступків.

Відповідно до ч. 1 ст. 86 КПК України доказ визнається допустимим, якщо він отриманий у порядку, встановленому цим Кодексом.

До критеріїв допустимості доказів у науці кримінального процесу традиційно відносять: 1) належний суб' єкт, правомочний провадити процесуальні дії, спрямовані на формування доказів; 2) надійність фактичних даних, що складають зміст доказу; 3) дотримання вимог процесуальної форми під час формування відповідного виду доказів; 4) етичність тактичних прийомів, які використовуються для одержання доказів [15, с. 120]. М.М. Кіпніс вказує, що допустимість доказу характеризує його з погляду законності джерела фактичних даних (інформації), а також засобів отримання і форм закріплення фактичних даних, які містяться в такому джерелі, у порядку, встановленому кримінальним процесуальним законом, уповноваженою на особою або органом у результаті проведення ним слідчої дії із суворим дотриманням кримінального процесуального закону, в якому визначені форми такої слідчої дії. Доказ має бути визнаний недопустимим, коли 
процесуальна дія здійснюється особами, які: взагалі не уповноважені на ії проведення; мають право на проведення таких дій, але підлягають відводу; мають право на проведення таких дій, але не на цій процесуальній стадії або не у провадженнях цієї категорії [16, с. 27, 30].

Таким чином, допустимість доказів включає такі елементи, як: законність джерела доказів; законність способу отримання доказів; процесуальне оформлення отримання доказів; належний суб'єкт отримання доказів.

Важливість належного суб'єкту отримання доказів підтверджується і судовою практикою. Згідно з п. 19 постанови Пленуму Верховного Суду України № 9 від 1 листопада 1996 року «Про застосування Конституції України при здійсненні правосуддя» докази повинні визнаватись такими, що одержані незаконним шляхом, тоді, коли їх збирання й закріплення здійснено або 3 порушенням гарантованих Конституцією України прав людини і громадянина, встановленого кримінально-процесуальним законодавством порядку, або не уповноваженою на це особою чи органом, або за допомогою дій, не передбачених процесуальними нормами.

Відповідно до висновку Конституційного Суду України у справі за конституційним поданням Служби безпеки України щодо офіційного тлумачення положення ч. 3 ст. 62 Конституції України від 20 жовтня 2011 року, обвинувачення у вчиненні злочину не може бути обгрунтоване фактичними даними, одержаними в незаконний спосіб, а саме: 3 порушенням конституційних прав і свобод людини і громадянина; з порушенням встановлених законом порядку, засобів, джерел отримання фактичних даних; не уповноваженою на те особою тощо.

На думку авторів коментаря КПК України 2012 року, перелік належних суб'єктів, що мають право на отримання доказів, викладається у ч. 1 ст. 84 КПК України - це слідчий, прокурор, слідчий суддя і суд, що здійснюють конкретне кримінальне провадження [17, с. 254].

Слід навести думку А. Павлишина, який наголошує, що у ст. 84 КПК України не визначено переліку суб'єктів, котрі можуть отримувати (збирати) докази, а визначає суб'єктів, котрі можуть визнавати певні відомості доказами, в тому числі й ті, що отримані як стороною захисту, так і стороною обвинувачення, а це $є$ не зовсім логічним і загалом порушує вимоги змагальності. Якщо спиратися на такі вимоги, правом визнавати певні відомості доказами мав би бути наділений винятково слідчий суддя чи суд [18, с. 357].

Проте буквальне тлумачення ч. 1 ст. 84 свідчить, що в ній йдеться саме про суб'єктів кримінального процесу, на яких покладається обов'язок встановлювати наявність чи відсутність фактів та обставин, що мають значення для кримінального провадження та підлягають доказуванню, а також приймати відповідні процесуальні рішення. Тому не можна, на наш погляд, виключати 3 цього переліку дізнавача з огляду на те, що у провадженнях про кримінальні проступки на нього покладається обов'язок доказування обставин, які входять до предмету доказування.

Таким чином, вважаємо необхідним внести зміни до ст. 84 КПК України та передбачити дізнавача в переліку суб'єктів кримінального процесу, на яких покладається обов'язок встановлювати наявність чи відсутність фактів та обставин, що мають значення для кримінального провадження та підлягають доказуванню.

Важливим для доказування $є$ також дослідження питання доказів та їх джерел у провадженні щодо кримінальних проступків. У кримінальному процесуальному законодавстві не надано визначення такого поняття, як джерело доказів. У ч. 2 ст. 84 КПК України вказано, що процесуальними джерелами доказів є показання, речові докази, документи, висновки експертів.

У кримінальній процесуальній науці процесуальні джерела доказів розуміють як носії інформації, які були одержані і закріплені у кримінальній справі з додержанням процесуальної форми. При цьому джерела доказів не є ані невіддільною складовою частиною доказів, ані доказами в одному з двох тлумачень. Створюючи з доказами діалектичну єдність, їх джерела не втрачають самостійного значення для доказування у кримінальних справах. [19, с. 42, 43].

О.П. Острійчук вказує, що процесуальне джерело доказів - це об'єкт матеріального світу або інформація, що містить у вигляді матеріальних або ідеальних слідів фактичні дані про кримінальне правопорушення та про пов'язані з ним обставини, які підлягають доказуванню у кримінальному провадженні, що виявляють, закріплюють і досліджують сторони кримінального провадження у встановленому законом порядку з пізнавальною метою прийняття законного та обгрунтованого рішення у кримінальному провадженні [20, с. 749].

У Законі України «Про внесення змін до деяких законодавчих актів України щодо спрощення досудового розслідування окремих категорій кримінальних правопорушень» від 22 листопада 2018 року передбачено доповнення КПК України статтею $298^{-1}$ - «Процесуальні джерела доказів у кримінальних провадженнях про кримінальні проступки, в якій визначено, що проце- 
суальними джерелами доказів у кримінальному провадженні про кримінальні проступки, крім визначених статтею 84 цього Кодексу, також $є$ пояснення осіб, результати медичного освідування, висновок спеціаліста, показання технічних приладів і технічних засобів, що мають функції фото- і кінозйомки, відеозапису, чи засобів фото- і кінозйомки, відеозапису.

Такі процесуальні джерела доказів не можуть бути використані у кримінальному провадженні щодо злочину, окрім як на підставі ухвали слідчого судді, яка постановляється за клопотанням прокурора [21].

О.В. Сачко справедливо зазначає, що така спеціальна система джерел доказів не узгоджена із загальним поняттям доказів та правилами визначення їх допустимості, має штучний і нелогічний характер, який не зовсім відповідає теорії пізнання, теорії інформації, взагалі ігнорує таку науку, як логіка. Важливою умовою якості закону є єдність та виваженість процесуальної форми. Закон має чітко назвати засоби отримання доказів та виважено регламентувати процедуру їх застосування $з$ тим, щоб забезпечувати як отримання достовірних доказів, так і дотримання принципів пропорційності та захисту прав і свобод людини. Законодавцю мало назвати якісь нові форми отримання доказів, які можуть бути і доречними, важливо прописати в законі порядок застосування нових форм [22, с. 175].

Висновки. Підсумовуючи, можна резюмувати, що запропоновані джерела доказів не відповідають загальній теорії доказового права і не можуть бути використані для доказування у провадженнях про кримінальні проступки. Запроваджувані як джерела доказів у провадженні щодо кримінальних проступків, вони виходять за межі кримінальної процесуальної форми, адже фактично йдеться про отримання відомостей до початку кримінального провадження, що, на нашу думку, є недоцільним.

В той же час у кримінальному процесуальному законодавстві вже передбачені джерела доказів, які за змістом охоплюють нові спеціальні джерела. Так, у межах кримінального провадження можуть бути джерелом доказів показання замість пояснення осіб. Результати медичного освідування та висновок спеціаліста, які надані до внесення відомостей до Єдиного реєстру досудового розслідування, можуть використовуватись в межах такого джерела доказів, як документи. Крім того, медичне освідування у кримінальному провадженні має здійснюватись в межах такої слідчої дії, як освідування особи, що передбачена ст. 241 КПК України. Вказане сприятиме забезпеченню прав осіб у провадженні щодо кримінальних проступків, адже саме додержання кримінальної процесуальної форми є запорукою ефективного виконання завдань кримінального провадження з додержанням балансу інтересів держави і особи.

\section{Список використаних джерел:}

1. Строгович М.С. Курс советского уголовного процесса. Москва, 1968. Т. 1. 470 С.

2. Михеєнко М.М., Нор В.Т., Шибіко В.П. Кримінальний процес України. Київ, 1992. 431 с.

3. Тертышник В.М. Уголовный процесс. Харьков, 1997. 528 С.

4. Стахівський С.М. Кримінально-процесуальні засоби доказування: автореф. дис. на здобуття наук. ступеня доктора юрид. наук : спец. 12.00.09 «кримінальний процес та криміналістика; судова експертиза; оперативно-розшукова діяльність». Київ, 2005. 29 с.

5. Капліна О. Кримінальне процесуальне доказування та його суб'єкти: лекція. Право Украӥни. 2014. № 137. С. 136-147.

6. Кримінальний процесуальний кодекс України від 13 квітня 2012 року № 4651-VI. URL: http://zakon4.rada.gov.ua/laws/show/4651-17.

7. Кримінальний процесуальний кодекс України від 13 квітня 2012 року № 4651-VI. URL: http://zakon4.rada.gov.ua/laws/show/4651-17.

8. Попелюшко В.О. Предмет доказування в кримінальному процесі (процесуально-правові та кримінально-правові аспекти). Острог, 2001. 196 с.

9. Дєєв М.В. Достатність доказів у кримінальному процесі України : дис. ... канд. юрид. наук : 12.00.09 / Дєєв Максим Валерійович. Київ, 2007. 218 с.

10. Тертышник В.М., Слинько С.В. Теория доказательств. Харьков, 1998. 256 с.

11. Погорецький М. Теорія кримінального процесуального доказування: проблемні питання. Право Украӥни. 2014. № 10. С. 12-25.

12. Стахівський С.М. Кримінально-процесуальні засоби доказування : дис. ... доктора юрид. наук : 12.00.09 / Стахівський Сергій Миколайович. Київ, 2005. 367 с.

13. Баулін О.В. Поняття доказів у кримінальному процесі. Вісник Національної академії прокуратури Украӥни. № 1 (47). 2017. С. 75-81. 
14. Кримінальний процесуальний кодекс України. Науково-практичний коментар : у 2 т. Т. 1 / О.М. Бандурка, С.М. Блажівський, С.П. Бурдоль та ін. ; за заг. ред. В.Я. Тація, В.П. Пшонки, А.В. Портнова. Харків : Право, 2012. 768 с.

15. Малярова В.О. Належність та допустимість доказів у кримінальному провадженні. Науковий вісник Ужгородського національного університету. Серія ПРАВО. 2016. Випуск 38. Том 2. С. 119-121.

16. Кипнис Н.М. Допустимость доказательств в уголовном судопроизводстве / Отв. ред. П.А. Лупинская. Москва : Юристь, 1995. 128 с.

17. Кримінальний процесуальний кодекс України. Науково-практичний коментар: у 2 т. Т. 1 / О.М. Бандурка, Є.М. Блажівський, Є.П. Бурдоль та інші ; за заг. ред. В.Я. Тація, В.П. Пшонки, А.В. Портнова. Харків : Право, 2012. 768 с.

18. Павлишин А. Окремі питання допустимості доказів за Кримінальним процесуальним кодексом України 2012 року. Вісник Львівського університету. Серія юридична. 2014. Випуск 59. C. $356-364$.

19. Сівочек С.М. Оцінка джерел доказів у кримінальному процесі: дис. ... кандидата юрид. наук : 12.00.09 / Сівочек Сергій Миколайович. Киев, 2003. 215 с.

20. Острійчук О.П. Поняття та система процесуальних джерел доказів у контексті реформування процеу доказування в кримінальному процесі. Форум права. 2013. № 1. С. 745-750.

21. Про внесення змін до деяких законодавчих актів України щодо спрощення досудового розслідування окремих категорій кримінальних правопорушень: Закон України № 2617-VIII від 22 листопада 2018 року https://zakon.rada.gov.ua/laws/show/2617-19.

22. Сачко О.В. Забезпечення верховенства права при застосуванні особливих форм, порядків та режимів кримінального провадження : дис. ... доктора юрид. наук: спец. 12.00.09. Дніпро. 2019. $488 \mathrm{c}$.

УДК 343.137: 341.44

DOI https://doi.org/10.32844/2618-1258.2019.6.54

БОРТНИЦЬКА В.В.

\section{МІЖНАРОДНА РЕГЛАМЕНТАЦІЯ ЗАСТОСУВАННЯ СПРОЩЕНОГО ПОРЯДКУ ВИДАЧІ ОСІБ}

Стаття присвячена аналізу міжнародної регламентації застосування спрощеного порядку видачі осіб. Здійснено класифікацію умов видачі особи. Визначено обов'язкові умови видачі, умови, наявність яких перешкоджає здійсненню видачі осіб, та умови, наявність яких дає право відмовити у видачі особи або погодитися на видачу особи залежно від обставин. Проаналізовано КПК України на предмет відповідності змісту Європейської конвенції про видачу правопорушників та додаткових протоколів до неї та визначено коло питань, які не знайшли відображення в КПК України. З'ясовано, що суб'єктами, які приймають участь у розгляді питання щодо тимчасового арешту або розгляду згоди про спрощений порядок видачі особи, є особа, яка підлягає видачі, iї захисник, прокурор, який звертається до слідчого судді з клопотанням про застосування тимчасового арешту або який приймає участь у розгляді питання щодо затвердження згоди особи на видачу, та слідчий суддя, який затверджує таку згоду. У разі, якщо запит про видачу правопорушника стосується декількох окремих правопорушень, кожне з яких за законами запитуючої Сторони і запитуваної Сторони карається позбавленням волі, але якщо деякі з них не задовольняють умови стосовно тривалості терміну покарання, яке може бути призначене, то запитувана Сторона має право здійснити видачу особи, якщо хоча б одне із правопорушень відповідає умовам стосовно тривалості термі-

(C) БОРТНИЦЬКА В.В. - здобувач (Харківський національний університет внутрішніх справ) 